\title{
A MEGAMORPHIC AND TWO CURIOUS MIMETIC FLIES
}

\author{
By Frank M. HulL \\ University of Mississippi
}

At a recent visit to the Carnegie Museum the writer was afforded the privilege of studying the unidentified Syrphid flies in the collections. Among this material were discovered certain curious types upon which it is desired to report at this time. The bulk of the material will be reported upon later. I wish to express my thanks to Dr. Hugo Kahl for the opportunity to study this material.

\section{Chysidimyia, new genus}

Eyes bare. Antennæ slender, third joint densely erect pubescent, the dorsal arista thickest in the middle. Whole face extended as a rounded lump anteriorly, a crease separating the lower face from the upper, and lying shortly above the oral margin. Antennæ inserted from ventral surface of an overhanging frontal shelf. Scutellum with two spines, moderately separated. Abdomen oval-elongate; the sides of the second segment greatly thickened and overlapping the corners of the succeeding segment making possible a downward deflection of the remainder of the abdomen. Whole lateral margins of the abdomen enormously thickened and inrolled; segments three, four and five entirely fused. Legs simple, an oblique groove on the basal part of hind femora.

Whole head, thorax, abdomen and legs everywhere brilliant metallic green and extraordinarily deeply punctate. The punctures are actual depressions, which on the posterior rim of the second abdominal segment, become grooves.

Wings with the posterior angles of the first posterior and discal cells rounded, that of the first posterior gives off a spur to wing margin. There is a spur cutting down towards the spurious vein from the third longitudinal vein.

Genotype: Chysidimyia chrysidimima new species. 
Chysidimyia chrysidimima new species

Eyes nearly touching, approaching in an angular fashion which is but little over a right angle, perhaps 110 degrees. Eyes quite noticeably short, whitish pilose. Vertex swollen, the eyes gradually excavated behind so that the occiput and post vertex is for some distance rounded and enormously thickened. Ocelli inserted at highest point, some distance from post occipital margin and almost midway from antennae. Antennæ situated a little above midline of profile, to the lower surface of a slight shelving prominence. The face below antennæ slightly excavated for a short distance, then swelling to large rounded mammiform area and falling off just a short distance before the oral margin, not right at the margin. A marginal crease delimits the very small cheeks. Lower occiput very thin. There is a vertical crease down the midline of face. Antennæ elongate, black, the first joint as long as the third; the second one-fifth or one-sixth of the third. The third is thickest just before the rounded apex. The arista is basally thickened, shorter than third and black and bare. Pile of face, except for a few dark hairs on front, whitish. Whole face and head everywhere deeply and remarkably punctate.

Pile of thorax quite short, very appressed, black with a few pale hairs. Scutellum armed with two short spines set slightly closer than length of scutellum in midline.

Abdominal pile short, scanty, appressed, black with a few pale hairs and in the margins more pale hair. The greatly thickened tergites at the sides are inrolled and the apical margin of the second segment is greatly thickened and equipped at the corners to overlap the rest of the abdomen in down folding.

Legs black, the terminal tarsal joints dark brown; the tibiae and femora metallic green, with small punctures; the hind basitarsi not extraordinary, nor the hind femora greatly thickened. Wings grey, terminal section of fourth longitudinal vein straight, a spur dropped from third longitudinal vein into the first posterior cell. Spurious vein present.

Length $9 \mathrm{~mm}$.

One male. Santarem, Brazil, June 1919. (S. M. Klages). Accession 6324. Type in the Carnegie Museum. 
The whole insect is remarkably brilliant blue-green, metallic, vitreous, covered everywhere with deep punctures or pits, and on the abdomen small creases, in shape and appearance presenting an astonishing resemblance to a Chrysidid wasp, altogether the most remarkable case of mimicry I have ever beheld.

\section{Tityusia new genus}

Large flies, the males narrowly holoptic, the upper facets slightly enlarged, the antennal prominence well developed, the antennæ have the third joint suborbicular and the arista bare. First and second joints short. Face with a very low median tubercle, not greatly produced either anteriorly or ventrally. Post-occiput flared posteriorly backwards about central opening, and long pilose.

Thorax and scutellum normal, with very dense pile of median length, the rim of the latter simple. Metanotum with a horizontal depression or crease. Abdomen broadly oval, broad basally, tapering posteriorly, yellow maculate somewhat similar to species of Helophilus and Mesembrius.

Hind femora moderately thickened, but unarmed posteriorly with either spines or setae. The black basal patch of setulae present. Anterior femora greatly thickened, especially apically and from the apical third of the posterior margin a very thick brush of dense dark pile is sent backward, much as if the hairs of a brush had been wetted. Fore tibiæ still more extraordinary, enormously thickened, grooved, twisted and distorted, the median and lateral edges bare, dense fringes of dark pile extremely long, extremely matted, directed backward. Fore tarsi extravagantly flattened on the dorso-ventral axis, the lateral edges of the second, third and fourth segments prolonged into narrow down curving lobes. Median pair of legs simple, except that their tarsi are flattened somewhat. Posterior tibiae slightly flattened. Posterior basitarsi nearly as long as post tibiae, on its distal end bearing an enormous brush of dark matted hair, its basal end equipped with the characteristic globuliferous hairs of Mesembrius. Marginal cell of wings narrowly open. Halteres long stalked, the knob with a deep cup shaped depression. This may be due to drying.

Genotype: Tityusia regulus new species. 
Tityusia regulus new species

Male. Eyes bare, touching narrowly. Vertical triangle quite narrow. Frontal (antennal) prominence well developed, shining brownish black. Face and cheeks similarly colored, the former light yellow on the sides and covered with pale yellow pubescence and similar longer pile, the pubescence being sparse on the weak low tubercle. Pile of front and vertex black, of occiput above and below, long and pale golden in color. Antennæ and arista dark brown.

Thoracic dorsum black, opaque or at best subshining, an obscure yellowish pollinose stripe on the middle of either side, and even more obscure and narrower vitta lying on the midline. Anterior three-fifths of dorsum clothed with dense moderately long, pale golden pile, the tips of the hairs crinkled and a few very fine black hairs intermixed. The posterior part of dorsum, short, thick, black pilose, the scutellum golden pilose. All the thoracic pile very erect. The brown humeri largely bare, what pile is present (including humeri) is long, tufted, crinkled, and pale golden.

Abdomen: first segment, the fore and hind borders of second and a narrow median connection widening quickly in either direction, dark brown to black. A brown subshining apical band on the third segment with its fore border raised into a low acute pyramid, and a similar apical band on the fourth segment with a rounded fore margin that nearly reaches the base of that segment, also dark brownish black but shining as well. This leaves two very large orange spots, shaped like the ends of a parabola on the second segment and a similarly colored band at the base of the third segment. The base of the fourth segment is densely greenish yellow pubescent. Pile on the surface of the segments and in the middle, black and appressed becoming more erect, longer and golden in color on the sides. Some straggled, curious, long, flat, appressed golden hairs on base of the second segment.

All the legs dark brownish to black, subshining, the very narrow bases of tibiae pale, and the tarsi varying shades of yellow brown. Pile of femora, except anterior pair, long, pale, crinkly. That of hind tarsi, fore tibiae and fore femora a most extraordinary mat of dense, excessively long hair. Fore tarsi pale, flattened and laterally produced in an extrav- 
agant way, reminding one of Platychirus. See the generic description for further details.

Length $18 \mathrm{~mm}$.

One male. Efufup, Kamerun, W. Africa, August 30, 1919. Carnegie Museum. Accession No. 6552. Holotype male in Carnegie Museum.

This fly is to the Syrphidae what Calotarsa is to the Platypezidae, a curious convergent type of structural development.

\section{Syrphipogon new genus}

Very large flies related to Microdon.

Eyes bare, broadly dichoptic in male. Antennae slender, the first joint sub-equal to last two. Arista thick, its surface pubescent. Hair of upper front directed upward, of vertex directed forward and upward so that the two converge above ocelli. Lower face just above mid oral margin equipped with a beard of long thick shining black bristles.

Thorax normal, thick black bristly, greatly appressed. Scutellum with a pair of enormous spines, deeply sulcate between, directed upward and posteriorward at an angle of 45 degrees. Abdomen broad and thick, the lateral posterior margins of the third segment and adjoining base of the fourth deeply sunken, followed by a simple situation on the next segment so that a strong ridge lies between. Hind basitarsi longer than remaining joints, greatly widened and flattened. Remaining joints similarly widened and flattened, but less so.

Last section of fourth longitudinal vein (subapical cross vein) bluntly angulate outward, just before terminus the posterior angles of the first posterior and discal cells not angulate but evenly rounded. No spurs except for the posterior cell spur cutting down to terminys of spurious vein. Wings black basally, blackish on a narrow distal apex, and yellow with yellow veins between.

Genotype: Syrphipogon fucatissimus new species.

\section{Syrphipogon fucatissimus new species}

Male. Whole face and head shining black, the face with a faint purplish tinge. Arista pale yellow. Antennae black, 
elongate. Last two joints about as long as first, not set on a pedicel. Third joint one and three-fourths times length of second. Second about equal width of front at narrowest point. Pile of head and face everywhere black, vertical pile and that of upper front converging to come together just above ocelli. Pile of upper face exceedingly appressed, black, bristly, the face punctate, developed on the lower face into a black beard of long bristles above oral margin.

Dorsum of thorax shining black, covered thickly with very short appressed bristles, a few golden ones on the sutures. Pleurae similar but with longer bristly pile. Scutellum developed into a pair of enormous black spines, deeply sulcate in the middle, and black bristly or pilose to their apices. Spines held at a forty-five degree angle.

Abdomen shining black, a deep excavation on the apical lateral half of the third and again on the fourth segments. Apical half of second segment long, golden pilose, a similar annulus or transverse band across the middle of the fourth segment so that the first excavation lies between and is black. Remainder of abdomen, except for a little more black following the second golden band, is deep bright orange reddish pilose.

Legs everywhere dark shining black, black bristly, the hind metatarsi (and the following ones to a less extent) enormously flattened and broadened, but not markedly thick.

Wings with basal half or three-fifths black, (very dark brown) the remainder except for light brown tip, yellow with yellow veins.

Length $25 \mathrm{~mm}$.

South America, without further data. Type in the Carnegie Museum.

Curiously, this fly forms part of a three-part mimetic complex, the others being an Asilid fly and a bee from the same region. 



Submit your manuscripts at

http://www.hindawi.com
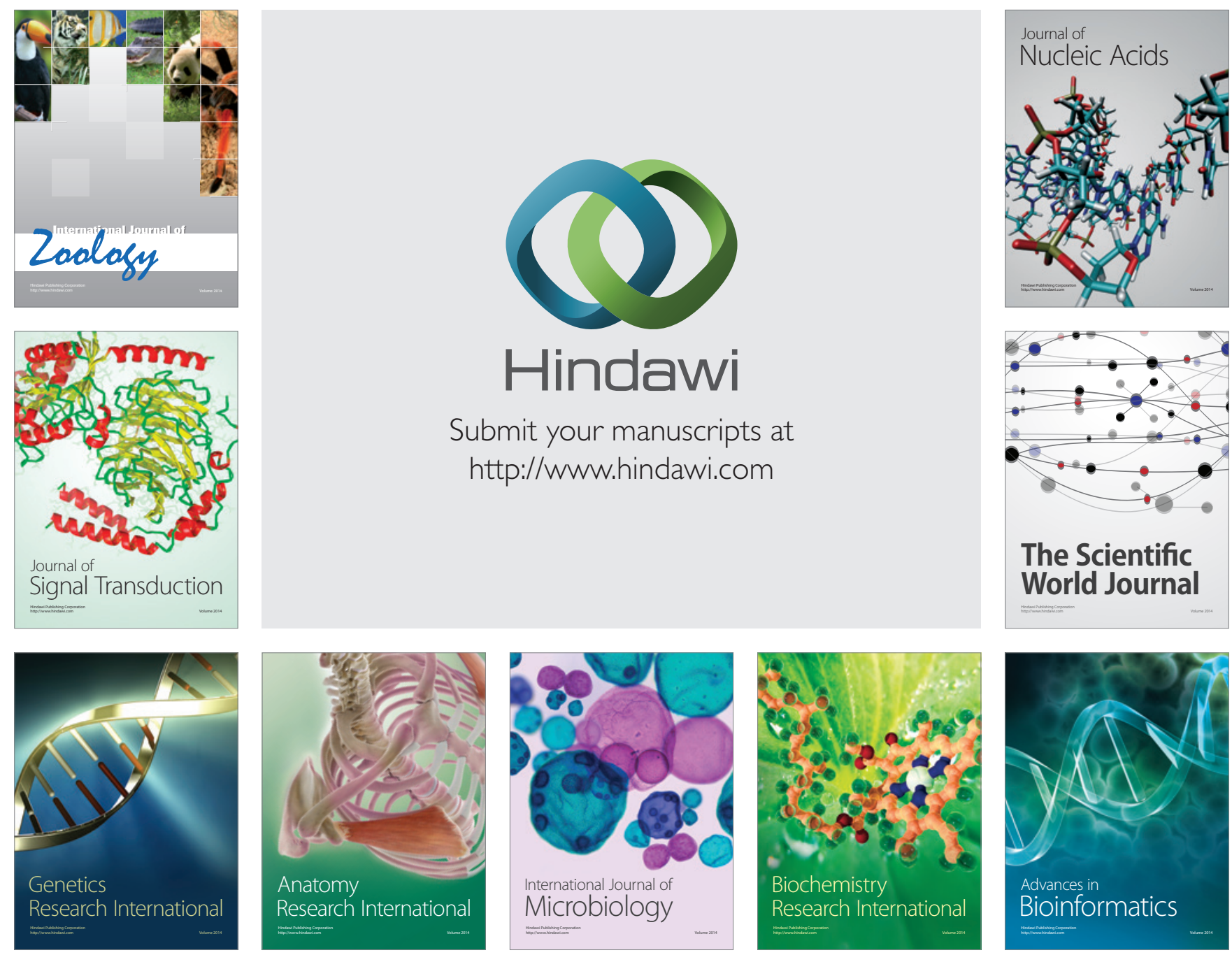

The Scientific World Journal
